\title{
KEMASAN MAKANAN KULINER TRADISIONAL "MEGONO" SEBAGAI UPAYA MEMPERPANJANG WAKTU SIMPAN DAN DAYA SAING PRODUK
}

\author{
Indar Widowati*, Hartati, Zaenal Amirudin \\ Program Studi D-III Keperawatan Pekalongan Politeknik Kesehatan Kemenkes Semarang \\ Jl. Perintis Kemerdekaan Pekalongan \\ Korespondensi: indarwidowati@gmail.com
}

\begin{abstract}
The shifting of the pattern of life of traditional communities to the pattern of modern society lives, encouraging people to choose ready-to-eat and ready-to-eat foods while considering the importance of health, which causes the need for food/beverage products to be able to maintain health and fitness, safe and practical in its presentation. Megono is one of the traditional culinary foods originating from the city of Pekalongan has the potential to meet the needs of modern society. This study aims to: 1) Develop the potential of traditional culinary food into innovative megono food products in packaging; 2) Analyze the type of packaging suitable for megono food, 3) Analyze the nutritional content of megono products in the package. The research methods include: engineering method for making megono, experimental method for canning, organoleptic method for determining selected formulas, laboratory methods for testing the nutritional content (proximate), experimental methods for testing product storage time. This study consists of several stages, namely the stage of making megono, the drying stage, the stage of testing of the nutrient content (proximate), the product storage time test phase. The results of the organoleptic test proved that the most megono cans chosen by respondents were megono B (MGN 0.5) as much (84\%) with the half-cooked steaming method before the canning process. The MANOVA test results obtained diperoleh value of $0.00<0.05$, meaning that there is an influence of canning on the taste, aroma, texture and color of the megono. The proximate test results for every 100 gram megono B (MGN 0.5) contain: water of $72.43 \%$, carbohydrate $(17.33 \%)$, fat $(4.13 \%)$, ash $(3.17 \%)$, and protein (2.94\%). The time test for canned megono products that have been carried out is only limited to quarantine tests at Yogyakarta's BPTBA-LIPI which were declared to have passed quarantine and fulfilled the criteria for canned food packaging. Most $(84 \%)$ of respondents chose / liked the megono B can (MGN 0.5) product which is a half-cooked steamed megono before the canning process. The nutritional content of every 100 grams of megono cans B (MGN 0.5): water is $72.43 \%$, carbohydrates $(17.33 \%)$, fat $(4.13 \%)$, ash $(3.17 \%)$, and protein $(2$, $94 \%$ ). The product save time test cannot be done because of limited time and research funds.
\end{abstract}

\section{Keywords: Megono traditional food,Ccanned packaging, Product storage time}

\begin{abstract}
ABSTRAK
Bergesernya pola hidup masyarakat tradisional ke pola hidup masyarakat modern, mendorong masyarakat lebih memilih makanan siap saji dan siap santap dengan tetap mempertimbangkan pentingnya kesehatan, yang menyebabkan kebutuhan akan produk makanan/minuman diharapkan mampu berfungsi menjaga kesehatan dan kebugaran tubuh, aman dikonsumsi serta praktis dalam penyajiannya. Megono merupakan salah satu makanan kuliner tradisional berasal dari Kota Pekalongan memiliki potensi untuk memenuhi kebutuhan masyarakat modern. Penelitian ini bertujuan untuk: 1) Mengembangkan potensi makanan kuliner tradisional megono menjadi produk inovatif makanan_megono dalam kemasan; 2) Menganalisis jenis kemasan yang sesuai untuk makanan megono, 3) Menganalisis kandungan gizi pada produk megono dalam kemasan. Metode penelitian ini meliputi: metode engginering untuk pembuatan megono, metode ekspreimen untuk pengalengan, metode organoleptik untuk menentukan formula terpilih, metode laboratorium untuk menguji kandungan gizi (proksimat), metode eksperimen untuk uji waktu simpan produk. Penelitian ini terdiri atas beberapa tahap, yaitu tahap pembuatan megono, tahap pengalenhan, tahap uji kandungan gizi (proksimat), tahap uji waktu simpan produk. Hasil dari uji organoleptik membuktikan bahwa megono kaleng yang paling banyak dipilih oleh responden yaitu megono B (MGN 0,5) sebanyak (84\%) dengan metode pengukusan setengah matang sebelum proses pengalengan. Hasil uji MANOVA diperoleh $\rho$ value sebesar $0,00<0,05$, artinya ada pengaruh pengalengan terhadap rasa, aroma, tekstur dan warna megono. Hasil uji proksimat tiap 100 gram megono B (MGN 0,5) mengandung: air sebesar 72,43\%,
\end{abstract}


karbohidrat (17,33\%), lemak (4,13\%), abu (3,17\%), dan protein $(2,94 \%)$. Uji waktu simpan produk megono kaleng yang telah dilakukan hanya sebatas uji karantina di BPTBA-LIPI Yogyakarta yang dinyatakan lolos karantina dan memenuhi kriteria makanan kemasan dalam kaleng. Sebagian besar (84\%) responden memilih/menyukai produk megono kaleng B (MGN 0,5) merupakan megono yang dikukus setengah matang terlebih dahulu sebelum dilakukan proses pengalengan. Kandungan gizi tiap 100 gram megono kaleng B (MGN 0,5): air sebesar 72,43\%, karbohidrat $(17,33 \%)$, lemak $(4,13 \%)$, abu $(3,17 \%)$, dan protein $(2,94 \%)$. Uji waktu simpan produk belum dapat dilakukan karena keterbatasan waktu dan dana penelitian.

Kata Kunci: Makanan tradisional megono, kemasan kaleng, waktu simpan produk

\section{PENDAHULUAN}

Megono merupakan salah satu makanan kuliner tradisional nusantara yang berasal dari Pantai Utara Pulau Jawa Bagian Barat, tepatnya di Kota Pekalongan. Sebagai salah satu makanan khas tradisional warisan leluhur, perlu dijaga kelestariannya agar tidak tergeser oleh makanan-makanan modern. Salah satu cara untuk melestarikan makanan tradisional tersebut, yaitu dengan memperkenalkan kepada masyarakat, baik masyarakat sekitar maupun di luar Kota Pekalongan.

Namun, sampai saat ini megono masih disajikan secara tradisional, dibungkus dengan daun pisang dan tidak memiliki waktu simpan panjang. Hal ini menyebabkan para pendatang yang sengaja datang maupun yang singgah untuk beristirahat di Kota Pekalongan, tidak bisa membeli makanan megono untuk dibawa pulang sebagai oleholeh keluarga.

Disisi lain, dengan bergesernya pola hidup masyarakat tradisional ke pola hidup masyarakat modern, mendorong masyarakat lebih memilih makanan siap saji dan siap santap. Perubahan pola hidup masyarakat yang cenderung menyadari akan pentingnya kesehatan, menyebabkan kebutuhan pangan atau minuman diharapkan mampu berfungsi menjaga kesehatan dan kebugaran tubuh, aman dikonsumsi serta praktis dalam penyajiannya.

Untuk itu, gagasan untuk membuat megono menjadi makanan dalam kemasan, yang praktis dan tahan lama, tetapi juga menyehatkan perlu dilakukan. Umur simpan panjang dapat menjadi nilai tambah produk "Megono" dan membuka peluang untuk memperkenalkan pangan indegenous di luar wilayah Pekalongan, seperti pelancong, perantau, atau wisatawan batik dan religius yang berkunjung ke Pekalongan, bahkan diharapkan bisa sampai ke pasar domestik maupun mancanegara (go international).

Teknologi pengemasan dan pengawetan makanan terus dikembangkan oleh Balai Penelitian Teknologi Bahan Alam Lembaga Ilmu Pengetahuan Indonesia (BPTBA-LIPI) Yogyakarta. Riset tersebut dimaksudkan untuk menemukan jenis kemasan yang sesuai untuk memperpanjang umur simpan produk makanan, khususnya untuk jenis pangan berasam rendah yang umurnya relatif singkat. Kemasan fleksibel retort pouch berpotensi besar untuk dikembangkan di masa kehidupan modern yang menghendaki pilihan-pilihan yang bersifat praktis. Kemasan retort pouch merupakan alternatif bahan pengemas yang memiliki kelebihan dibanding makanan konvensional. Kelebihan tersebut, antara lain, mudah untuk dibawa karena lebih ringan, mudah dibuka, dan didaur ulang serta lebih murah dibandingkan pengalengan. Kemasan retort Pouch yang digunakan pada riset terdiri dari PET, Alumunium Foil, Nylon, RCPP berbentuk fleksibel. (Dnh, 2017) 
Saat ini Balai Penelitian Teknologi Bahan Alam Lembaga Ilmu Pengetahuan Indonesia (BPTBA-LIPI), telah mengemas sekitar 42 resep makanan kuliner tradisonal dengan teknologi retort pouch dan pengalengan, antara lain Gudeg Jogja, Sayur Lombok Ijo, Mangut Lele, Rendang, Oseng-oseng mercon, Kari Tempe, Bandeng Mercon, Gulai Ikan Patin, Opor Ayam, Rawon, Brongkos dan lain-lain (Dnh, 2017).

\section{RUMUSAN MASALAH}

Bertolak dari uraian tersebut pada latar belakang, maka rumusan masalah yang diajukan peneliti, yaitu "Bagaimanakah Produk Makanan Kuliner Tradisonal Megono Dapat Dibuat Dalam Kemasan?"

\section{TINJAUAN PUSTAKA}

\subsection{Nangka}

Nangka merupakan tanaman pohon yang berbuah, berasal dari India dan menyebar ke beberapa negara tropis sepreti Malaysia, Thailand, Filipina, Kamboja, Lengkuas dan Vietnam termasuk Indonesia (Shi dan Moy, 2005 dalam Anna Amania Khusnayaini (2011).

Umumnya nangka masak dikonsumsi dalam bentuk buah segar, nangka muda banyak dijadikan sayur seperti megono (Pekalongan), gudeg (Jogja dan Jawa Tengah), gulai dan pecel. Produk olahan daging buah nangka yang umum dijumpai adalah jus, wajik, pasta, dodol, sirup, dan produk awetan dalam kaleng. Daging buah nangka juga dapat dibuat pikel (asinan), kolak, manisan, dan sebagai pewangi minuman (Astawan, 2007 dalam Anna Amania Khusnayaini, 2011).

Nangka sangat mudah rusak pada suhu dingin, tetapi buahnya dapat dipertahankan setelah dipanen selama beberapa hari pada suhu $12^{\circ} \mathrm{C}$. Komposisi buah sekitar 75\% air, 25\% karbohidrat, dan sedikit protein (Rubatzky dan Yamaguchi, 1998 dalam Anna Amania Khusnayaini, 2011).

Nangka muda tiap 100 gram mengandung: air 85,4 g, energi 51,2 kkal, protein 2 g, lemak 0,4 g, serat kasar 1,94 g, karbohidrat 11,3 g, kalsium 45 mg, fosfor 29 mg, Fe 0,5 mg, vitamin A 25 SI, vitamin B1 0,07 mg, vitamin C 9 mg (Depkes, 1981, Muchtadi, 1981 dalam Anna Amania Khusnayaini, 2011).

\subsection{Megono}

Megono merupakan makanan berbahan dasar nangka muda khas dari daerah pantai utara (pantura) bagian barat khususnya Pekalongan. Untuk membuat megono, nangka muda dicacah atau dicincang menjadi potongan-potongan kecil. Bahan pelengkap lain adalah parutan kelapa muda. Nangka muda dan parutan kelapa muda dikukus bersama aneka bumbu dapur yang sudah dihaluskan. Bumbu halusnya antara lain bawang putih, bawang merah, cabai rawit, ketumbar, lada putih, kemiri, terasi, dan lengkuas. Biasanya ditambahkan pula irisan cabai merah, daun salam, serai, dan bunga kecombrang.

Setelah matang, nangka muda, parutan kelapa, beserta bumbunya dicampur hingga merata dan disajikan, biasanya di atas nasi putih. Konsep megono sangat sederhana, rasanya yang gurih menjadi pelengkap untuk nasi yang cenderung hambar. Megono dikonsumsi biasanya ditambahkan lauk lain seperti tempe mendoan, daging ayam, dan lain-lain.

Permasalahanya adalah megono memiliki daya simpan pendek, sebab apabila lebih dari satu hari akan terjadi reaksi enzymatik oleh bakteri, yang menyebabkan 
tidak layak untuk dikonsumsi, serta penyajiannya masih dikemas atau dibungkus secara tradisional dengan daun pisang.

\subsection{Makanan Kemasan}

Penelitian tentang makanan kaleng berbahan dasar nangka muda sudah sering dilakukan oleh Lembaga Ilmu Pengetahuan Indonesia (LIPI), menghasilkan gudeg dalam kaleng dengan kandungan gizi, antara lain: lemak 5,12\%, protein 5,33\%, Karbohidrat $12,47 \%$, Air $73,28 \%$, Abu1,72\% , yang memiliki daya simpan satu tahun (LIPI, 2010 dalam Anna Amania Khusnayaini, 2011).

Saat ini Balai Penelitian Teknologi Bahan Alam Lembaga Ilmu Pengetahuan Indonesia (BPTBA-LIPI), telah mengemas sekitar 42 resep makanan kuliner tradisonal dengan teknologi retort pouch dan pengalengan, antara lain Gudeg Jogja, Sayur Lombok Ijo, Mangut Lele, Rendang, Oseng-oseng mercon, Kari Tempe, Bandeng Mercon, Gulai Ikan Patin, Opor Ayam, Rawon, Brongkos dan lain-lain

\subsection{Mutu Produk}

Mutu adalah hal-hal tertentu yang membedakan produk satu dengan lainnya, terutama berhubungan dengan daya terima dari kepuasan konsumen (Kramer dan Twigg, 1970 daam Anna Amania Khusnayaini, 2011). Mutu merupakan tingkat keunggulan produk pangan yang meliputi karakteristik utama yang menentukan tingkat penerimaan produk (Vaclavik dan Christian, 2008 dalam Anna Amania Khusnayaini, 2011).

Ada dua aspek untuk menilai mutu pangan, yaitu subjektif dan nonsubjektif. Atribut subjektif meliputi: penampakan, tekstur, dan flavour, sedangkan atribut nonsubjektif meliputi mutu gizi dan bakterial. Mutu gizi dan bakterial dapat diukur secara objektif dapat menggunakan analisis kimia, perhitungan jumlah bakteri, maupun uji spesifik lainnya (Szczesniak, 1983 dalam Anna Amania Khusnayaini, 2011).

Menurut Ahmed dan Shivhare (2006) dalam Anna Amania Khusnayaini (2011), sayuran yang telah diproses mengalami beberapa kehilangan mutu selama proses dan penyimpanan. Atribut mutu utama sayuran yang mengalami proses termal antara lain warna, aroma, rasa, dan tekstur. Selain itu, terdapat atribut mutu yang tersembunyi seperti nilai gizi dan faktor keamanan (kimia dan mikrobial).

\subsection{Sterilisasi Komersial}

Sterilisasi komersial digunakan pada proses sterilisasi produk pangan karena kondisi steril absolut (bebas mikroba) sulit dicapai (Haryadi, 2000 dalam Anna Amania Khusnayaini, 2011). Pemanasan dalam proses sterilisasi dilakukan pada suhu tinggi (lebih dari $100^{\circ} \mathrm{C}$ ) dalam waktu yang cukup untuk membunuh spora bakteri (Syarief et al, 1989 dalam Anna Amania Khusnayaini, 2011).

Sterilisasi komersial sebagian besar digunakan untuk makanan dalam kaleng, plastik, atau botol. Makanan yang steril secara komersial berarti bebas semua mikroba, dan mempunyai daya simpan lama, tahan beberapa bulan sampai beberapa tahun.

Proses pengalengan harus diikuti dengan pengemasan hermetis, yaitu produk pangan dikemas dalam kemasan yang tidak memungkinkan terjadinya kontak antara bahan di dalam kemasan dengan lingkungan sekitar. Produk pangan yang dibuat memalui proses sterilisasi dan kemasan, kedap udara sehingga mencegah 
terjadinya rekontamisasi (Kusbandar et al, 2006 dalam Anna Amania Khusnayaini, 2011).

\section{BAHAN DAN ALAT}

Bahan untuk membuat megono meliputi; nangka muda, kelapa muda, bawang merah, bawang putih, kemiri, gula, garam, lengkuas, lada putih, ketumbar, kencur, terasi, daun salam, daun jeruk, cabai rawit, cabai merah, bunga kecombrang, batang serai, aquadest, campuran selenium, H2BO3 2\%, HCL, Kloroforom, pelarut lemak, larutan indikator, labu kjedahl, H2SO4.

Alat dalam penelitian ini meliputi: thermocouple, thermorecorder, kaleng, timbangan, thermometer, sendok, blender, pisau, talenan, baskom kecil, keranjang, panci sarang, kompor gas dan gas, piring, sendok makan, kertas tisu, pipet, tabung reaksi, alat titrasi, labu ukur, kertas saring, cawan, oven desikator.

\section{METODE}

Metode dalam penelitian ini meliputi: metode engineering untuk pembuatan megono, metode eksperimen untuk pengalengan, metode organoleptik untuk menentukan formula terpilih, metode laboratorium untuk menguji kandungan gizi (proksimat), metode eksperimen untuk uji waktu simpan produk.

\section{TAHAPAN PENELITIAN}

\subsection{Tahap Pertama (Pembuatan Megono)}

Pembuatan Megono mengikuti resep yang terdapat di masyarakat yang sudah berlaku secara turun-temurun dan sudah teruji pada penelitian sebelumnya. Tahap ini meliputi:

Penyiapan Nangka Muda dan Parutan Kelapa, bahan dasarnya yaitu: nangka muda dikupas, getahnya dihilangkan/dibersihkan, dipotong kecil-kecil, disisihkan, serta kelapa muda dikupas dan diparut agak kasar.

Penyiapan Bumbu: bumbu-bumbu yang dihaluskan meliputi: bawang merah, bawang putih, kemiri, gula, garam, lengkuas, lada putih, ketumbar, kencur, terasi, cabai rawit, batang serai. Bumbu-bumbu yang diiris meliputi: cabai merah, bunga kecombrang, daun salam dan daun jeruk.

Langkah selanjutnya adalah percampuran bahan baku

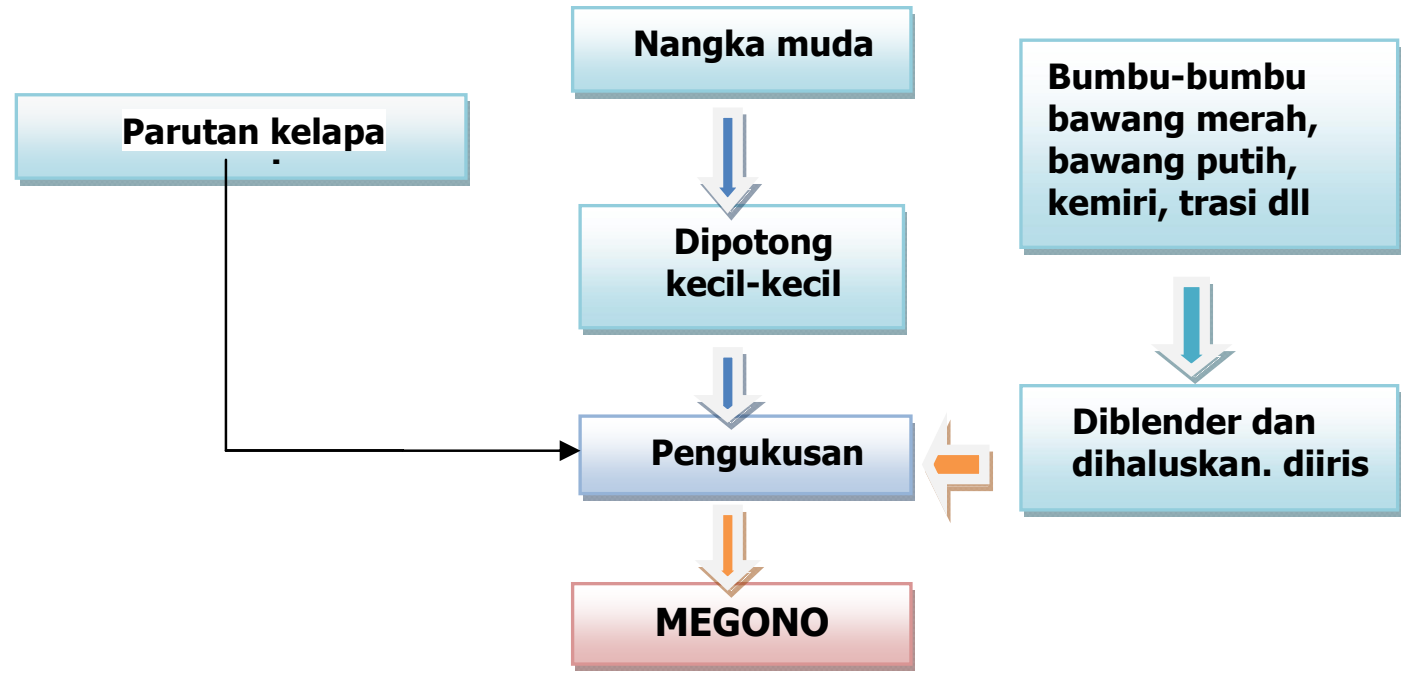

Gambar 1 Proses Pembuatan Megono 


\subsection{Tahap Pengalengan}

Proses pengalengan dilakukan di laboratorium BPTBA-LIPI Yogyakarta, dengan langkah-langkah sebagai berikut:

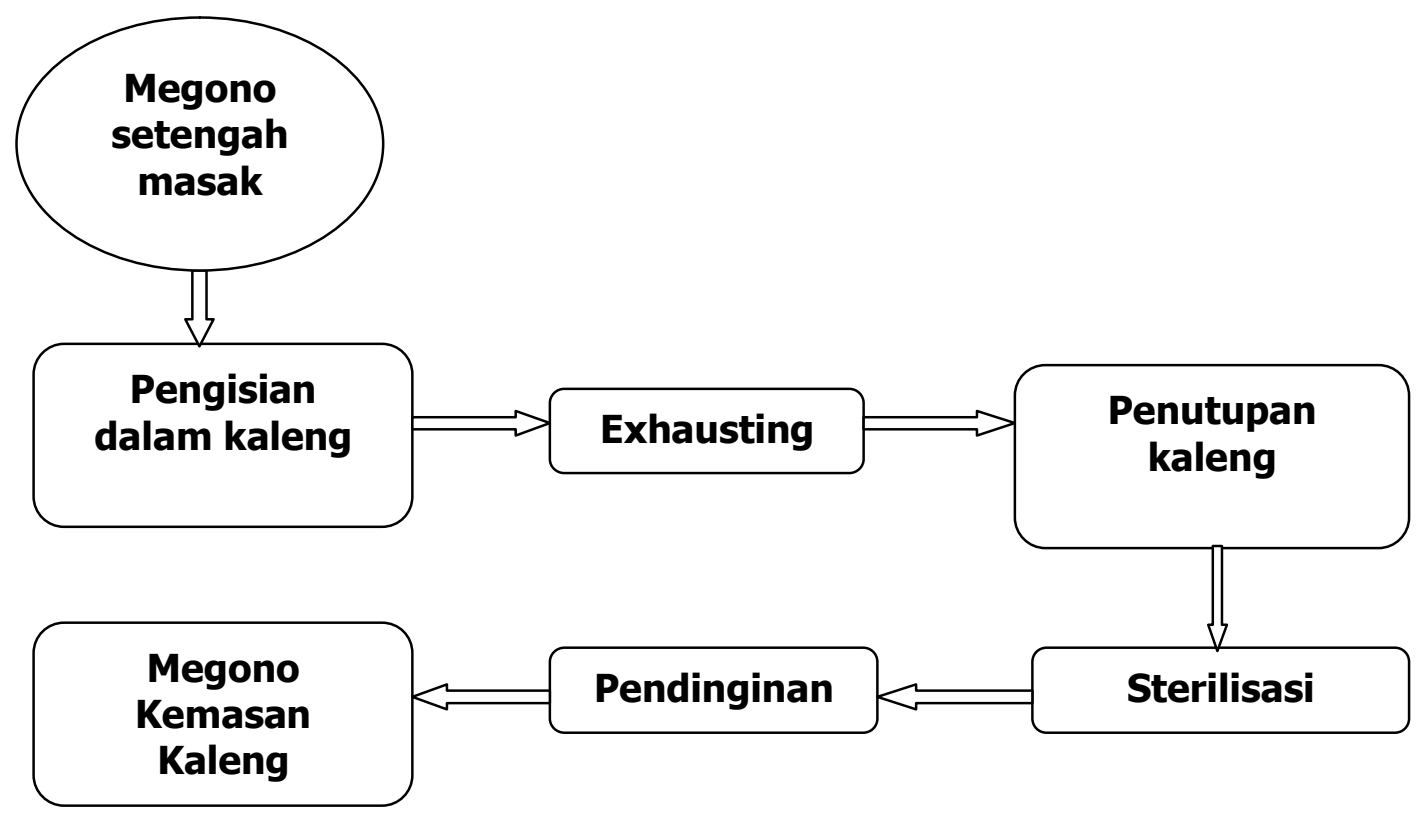

Gambar 2 Proses Pengalengan

Proses sterilisasi dilakukan pada suhu $121,1^{\circ} \mathrm{C}$, selama 10 menit, untuk memusnahkan mikroorganisme.

\section{ANALISIS}

Analisis pada penelitian ini, meliputi: analisis organoleptik terhadap warna, tekstur, rasa, aroma menggunakan uji peringkat. Sedangkan analisis untuk pengaruh pengalengan terhadap megono berhubungan dengan rasa, aroma, tekstur dan warna degan uji MANOVA.

Analisis proksimat, meliputi: kadar protein dengan metode Kjedahl, analisa kadar lemak dengan metode soxhlet, analisa kadar air degan metode pengeringan dioven, analisa kadar abu dengan metode pengabuan, dan analisa karbohidrat menggunakan Rumus: \% karbohidrat $(\mathrm{g} / 100 \mathrm{~g})=100-($ protein+lemak+abu+air), (Sudarmaji dkk, 1996), dalam Anna Amania Khusnayaini (2011) serta analisa pH menggunakan pH meter.

Analisis waktu simpan produk dan uji karantina menggunakan metode sterilisasi di di BPTBA-LIPI Yogyakarta

\section{HASIL PENELITIAN}

Hasil penelitian organoleptik megono kaleng menunjukkan bahwa megono kaleng yang paling banyak dipilih oleh responden adalah megono B (MGN 0,5) sebanyak 21 orang (84\%). Megono B (MGN 0,5) merupakan megono yang dikukus setengah matang sebelum proses pengalengan.

Hasil uji MANOVA diperoleh $\rho$ value sebesar $0,000<0,05$, artinya ada pengaruh pengalengan terhadap rasa, aroma, tekstur dan warna megono. 
Hasil uji proksimat menunjukkan bahwa megono B (MGN 0,5) tiap 100 gram mengandung: air sebesar 72,43\%, kemudian karbohidrat (17,33\%), lemak (4,13\%), abu $(3,17 \%)$, dan protein $(2,94 \%)$.

Uji waktu simpan produk belum dapat dilaksanakan karena keterbatasan waktu dan dana penelitian. Uji waktu simpan produk megono kaleng yang telah dilakukan hanya sebatas uji karantina di BPTBA-LIPI Yogyakarta yang dinyatakan lolos karantina. Berdasarkan hasil karantina tersebut peneliti bersama BPTBA-LIPI dapat menarik suatu kesimpulan bahwa megono tersebut memenuhi kriteria sebagai produk makanan kaleng.

\section{PEMBAHASAN}

\subsection{Uji Organoleptik}

Hasil penelitian menunjukkan bahwa megono kaleng yang paling banyak dipilih oleh responden yaitu megono B (MGN 0,5) sebanyak 21 orang (84\%). Megono B merupakan megono yang dikukus setengah matang sebelum proses pengalengan.

Megono merupakan makanan khas Pekalongan yang terbuat dari buah nangka muda atau biasa disebut cecek yang dicacah kecil-kecil dan tidak beraturan, dikukus bersama dengan parutan kelapa dengan penambahan bumbu lengkap dan cabai sehingga terasa gurih dan asin pedas. Nasi megono selalu tersedia dalam makanan sehari-hari masyarakat Pekalongan. Masyarakat Pekalongan asli tidak pernah bosan dengan megono bahkan masyarakat Pekalongan yang merantau di luar Pekalongan akan merasa rindu dengan megono asli tanah kelahirannya (Murdjiatik dkk dalam Gardjito, Rhaesfaty \& Dewi, 2018).

Berdasarkan pendapat tersebut maka peneliti membuat suatu inovasi untuk membuat produk megono kaleng agar dapat disitribusikan keluar Pekalongan. Pembuatan megono kaleng dimaksudkan untuk mengenalkan makanan khas Pekalongan kepada masyarakat di luar Pekalongan, memenuhi kebutuhan dan keinginan orang Pekalongan yang merantau di luar Pekalongan.

Bila dilihat dari sisi ekonomi, pembuatan produk megono kaleng ini dapat membuka lapangan kerja dan menghidupkan Usaha Mikro, Kecil dan Menengah (UMKM) di Kota Pekalongan. Produk ini diharapkan mampu memberikan keuntungan secara ekonomi bagi produk pengolahan makanan dan industry wisata terutama kuliner sebagai ciri khas Pekalongan.

Produk ini dapat bersinergi dengan industri wisata yang telah mempunyai produk unggulan batik sebagai obyek wisata belanja. Sinergitas ini diharapkan mampu meningkatkan pemasaran produk megono kaleng dan mengenalkan megono sebagai makanan tradisional khas Pekalongan.

\subsection{Pengaruh Pengalengan Terhadap Megono}

Berdasarkan hasil penelitian diketahui bahwa ada pengaruh pengalengan terhadap rasa, aroma, tekstur dan warna megono. Proses pengalengan berpengaruh terhadap kualitas rasa, aroma, tekstur dan warna megono.

Rasa megono kaleng B (MGN 0,5) yang dikukus setengah matang sebelum proses pengalengan sama seperti megono non kaleng merupakan rasa megono yang terbaik dibandingkan megono A (MGN) dan C (MGN 0). Megono A yang melalui pengukusan sempurna atau matang sebelum proses pengalengan mengalami perubahan rasa menjadi lebih asam, sedangkan megono $\mathrm{C}$ yang tidak dikukus 
terlebih dulu sebelum proses pengalengan mempunyai rasa yang kurang meresap, karena proses pengukusan hanya pada saat proses pengalengan.

Aroma megono B yang dikukus setengah matang sebelum proses pengalengan lebih sedap dibandingkan yang dikukus sempurna (megono A) dan yang tidak dimasak (megono C). Megono $\mathrm{C}$ mempunyai aroma paling rendah karena megono tidak dimasak terlebih dahulu sebelum proses pengalengan. Pemasakan dengan dikukus dapat mengeluarkan aroma yang sedap dari perpaduan bumbu-bumbu dalam megono.

Tekstur megono B yang dikukus setengah matang sebelum proses pengalengan sempurna seperti megono non kaleng. Megono C mempunyai tekstur kurang karena masih seperti megono mentah, sedangkan megono A yang dikukus sempurna sebelum proses pengalengan mempunyai rata-rata tekstur terendah karena megono setelah melewati proses pengalengan menjadi sangat lembek seperti gudeg.

Warna megono B yang dikukus setengah matang sebelum proses pengalengan sempurna seperti megono non kaleng. Megono C mempunyai warna lebih terang, sedangkan megono A yang dikukus sempurna sebelum proses pengalengan mempunyai rata-rata warna terendah karena warna megono lebih gelap dibanding warna megono non kaleng.

\subsection{Uji Proksimat Megono Kaleng}

Hasil uji laboratorium (uji proksimat) terhadap ketiga jenis megono kaleng yaitu megono A (MGN), megono B (MGN 0,5), dan megono C (MGN 0) membuktikan bahwa kandungan gizi terbesarnya ketiga megono kaleng tersebut adalah air. Kandungan air pada megono A (MGN) yaitu 67,34\%, megono B (MGN 0,5) $72,43 \%$, dan megono C (MGN 0) 76,10\%. Kandungan air yang terdapat pada ketiga sampel megono kaleng tidak terdapat perbedaan yang bermakna, ketiga sampel megono kaleng mengandung kadar air yang relatif tinggi. Hal ini dikarenakan pada saat proses pengalengan (canning) suatu produk yang dikalengkan akan mengalami tahap exhausting. Exhausting merupakan proses penghampaan udara pada megono yang telah dilakukan pewadahan (dimasukkan ke dalam kaleng dan belum dilakukan penutupan). Proses ini bertujuan untuk menngurangi atau menghilangkan gas udara yang terdapat pada bahan yang telah dikemas, karena udara tersebut merupakan sumber kontaminasi. Exhausting suhu $121,1^{\circ} \mathrm{C}$, selama 10 menit, untuk memusnahkan mikroorganisme.

\subsection{Uji Waktu Simpan Produk}

Hasil penelitian membuktikan bahwa megono lolos uji karantina. Uji karantina merupakan uji untuk menentukan apakah suatu bahan makanan layak dikemas dalam kaleng. Uji karantina membutuhkan waktu minimal 14 hari setelah proses pengalengan. Selain itu, kriteria lain yaitu kondisi kaleng yang dalam masa karantina tidak menggelembung, tidak terjadi kebocoran, dan setelah masa karantina produk diuji coba (organoleptik) untuk memastikan apakah kondisi fisik produk (tekstur, warna, rasa, dan aroma) dalam keadaan baik atau rusak.

\section{KESIMPULAN DAN SARAN}

\subsection{Kesimpulan}

Merujuk pada hasil penelitian, maka dapat disimpulkan sebagai berikut: 
a) Hasil uji organoleptik megono kaleng bahwa sebagian besar (84\%) responden memilih/menyukai produk megono kaleng B (MGN 0,5) merupakan megono yang dikukus setengah matang terlebih dahulu sebelum dilakukan proses pengalengan.

b) Hasil uji proksimat tiap 100 gram megono kaleng B (MGN 0,5) mempunyai kandungan gizi: air sebesar 72,43\%, karbohidrat (17,33\%), lemak (4,13\%), abu $(3,17 \%)$, dan protein $(2,94 \%)$.

c) Hasil uji MANOVA diperoleh $\rho$ value sebesar $0,000<0,05$, artinya ada pengaruh pengalengan terhadap rasa, aroma, tekstur dan warna megono.

d) Uji waktu simpan produk megono kaleng belum dapat dilakukan karena keterbatasan waktu dan dana penelitian.

\subsection{Saran}

a) Perlunya penelitian lanjutan untuk mengetahui waktu simpan produk megono kaleng.

b) Perlunya dukungan dana dari pemerintah kota Pekalongan untuk riset lanjutan produk megono kaleng sehingga dapat dikonsumsi dengan aman (memenuhi syarat kesehatan, waktu simpan produk), memenuhi standar MUI (halal), siap dipasarkan, dan memiliki hak paten atau hak kekayaan intelektual (HKI).

c) Perlunya kerjasama dengan UMKM sebagai pengelola makanan kuliner tradisional megono untuk memproduksi dan mengembangkan produk megono kaleng yang memiliki daya saing dengan produk makanan kemasan lainnya.

\section{DAFTAR PUSTAKA}

Anna Amania Khusnayaini. 2011. Pengaruh Tingkat Sterilitas Pada Proses Pengalengan Terhadap Sifat Fisik Gudeg Yang Dihasilkan. Skripsi, FTP IPB, Bogor

Dnh. 2017. 42 Jenis Makanan Tradisional Sudah Dikemas dengan Teknologi Kemasan. http://jogja.tribunnews.com/2017/09/08/42-jenis-makanan-tradisional-sudah-dikemasdengan-teknologi-kemasan. diakses 1/4/2018

Gardjito, Rhaesfaty \& Dewi.2018. Profil Struktur, Bumbu, dan Bahan dalam Kuliner Indonesia. Gadjah Mada University Press. Yogyakarta

Indar Widowati, Hartati, Zaenal Amirudin. 2017. Pengembanan makanan lokal "Megono Laktagenik" sebagai diversifikasi pangan untuk meningkatkan produksi ASI dan memacu pertumbuhan bayi. Pemerintah Kota Pekalongan badan Perencanaan Pembangunan, Penelitian, Dan Pengembangan Daerah

Rozali , Zalniati. 2009. Pengalengan Makanan. Institut Pertanian Bogor 